\title{
Policy and guidance
}

\section{A CURRICULUM FOR TRAINING HEALTHCARE WORKERS IN THE MANAGEMENT OF HIGHLY INFECTIOUS DISEASES}

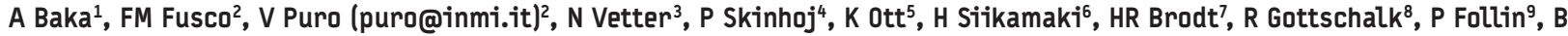 \\ Bannister ${ }^{10}, \mathrm{G}$ De Carli $^{2}$, C. Nisii ${ }^{2}$, J Heptonstall ${ }^{11}, \mathrm{G}$ Ippolito ${ }^{2}$, on behalf of the European Network of Infectious Diseases*
}

1. Hellenic Center for Disease Control and Prevention, Athens, Greece

2. National Institute for Infectious Diseases L. Spallanzani, Rome, Italy

3. Otto-Wagner-Spital (Otto-Wagner Hospital), Wien, Austria

4. Rigshospitalet (The State Hospital), Copenhagen, Denmark

5. West Tallinn Central Hospital, Tallinn, Estonia

6. Helsinki University Central Hospital, Helsinki, Finland

7. University hospital, Johann Wolfgang Goethe Universität, Frankfurt, Germany

8. Gesundheitsamt Stadt Frankfurt (City Health Service Frankfurt), Frankfurt, Germany

9. Smittskyddsinstitutet (Swedish Institute for Infectious Disease Control), Stockholm, Sweden

10. Royal Free Hospital, London, United Kingdom

11. Scarborough and North East Yorkshire Healthcare Trust, Scarborough, United Kingdom

The SARS epidemic, the threat of bioterrorism, and recent examples of imported highly infectious diseases (HID) in Europe have all highlighted the importance of competent clinical and public health management of infectious disease emergencies. Although the European Union of Medical Specialists in Europe and the Infectious Diseases Society of America have developed curricula for training in infectious disease medicine, neither of those mentions training in the management of HIDs. The European Network for Infectious Diseases (EUNID, http://www.eunid.com) is a European Commission co-funded network of experts in HID management, created to help improve the preparedness for HID emergencies within Europe. One of EUNID's agreed tasks is the development of a curriculum for such a training. Between April 2005 and September 2006, EUNID developed a curriculum and accompanying training course on the basis of a questionnaire that was sent to all country representatives and discussion, followed by amendment of drafts shared through the project website, and a final consensus meeting. The resulting curriculum consists of a two-module course covering the core knowledge and skills that healthcare workers need to safely treat a patient who has, or who may have, an HID. The first module introduces theoretical aspects of HID management, including disease-specific knowledge, infection control, and the public health response, through didactic teaching and class-based discussion. The second module involves a "skill station" and a clinical scenario, and equips trainees with relevant practical skills, including the use of specialised equipment and teamwork practice in patient management. Together, the curriculum and course contribute to the creation of a common framework for training healthcare professionals in Europe, and although they are designed primarily for clinicians that are directly involved in patient care, they are relevant also to public health professionals and others who may be involved in HID management and emergency response.

\section{Introduction}

Recent public health emergencies of global impact involving infectious agents and/or diseases (e.g. the deliberate release of letters containing anthrax spores via the US Postal Service in 2001 and the epidemic of severe acute respiratory syndrome (SARS) in 2002-2003), and incidents in Europe concerning the importation of highly infectious diseases (HID), such as viral haemorrhagic fevers, have drawn attention to the importance of competent clinical and public health management of infectious disease emergencies, and the need to improve preparedness within Europe for emerging health threats [1-5]. The European Commission, within its Public Health and Risk Assessment Programme, is funding a number of activities intended to improve health security, build capacity, and strengthen preparedness for response to infectious disease emergencies. This includes the European Programme for Intervention Epidemiology Training (EPIET, http://www.epiet.org), a network of containment level 4 (P4) laboratories (Euro-P4), European Training in Infectious Disease Emergencies (ETIDE, http://ec.europa.eu/health/ph_ projects/2005/action2/action2_2005_2_en.htm) targeting emergency departments, and the European Network for Infectious Diseases (EUNID, http://www.eunid.com) [6].

EUNID was created to exchange information, share best practice, develop training, and improve the connections between national (or regional) isolation units. It is a network of clinicians experienced in the management of HID, who represent national (or regional) infectious disease units designated to the care of patients with HID, including four high-level isolation units (HLIU), in Frankfurt/Main (Germany), Rome (Italy), Stockholm (Sweden), and London (United Kingdom). Most members are infectious disease clinicians, but the group also covers expertise from public health and epidemiology to emergency preparedness, pulmonary medicine, microbiology, infection control, and critical care medicine.

Infectious disease medicine is formally recognised as an independent specialty or subspecialty in most, but not all, countries in Europe [7]. It is still a relatively young specialty - the European Union of Medical Specialists (UEMS), created by statute in 1958 to 'harmonise and improve' the quality of medical specialist practice in the European Union (EU), has had a section of infectious diseases only since 1997 - and there is considerable debate about the ways in which the specialty should evolve and about the degree to which training in infectious disease medicine should be integrated into training in public health/epidemiology, microbiology, and infection prevention and control [8]. 
The European Union of Medical Specialists has developed a core curriculum for training in clinical infectious diseases and a training logbook to assist countries without a written curriculum in order to facilitate the development of common standards of training in infectious disease medicine within Europe $[9,10]$. In North America, the Infectious Diseases Society of America (IDSA) published a consensus-based core curriculum for clinical training in adult infectious disease medicine in 1998. [11] The curricula of both organisations are based on training in general medicine, involve clinical and research components, and require experience in medical microbiology, infection control and public health medicine in addition to a commitment to continuing medical education. The European Union of Medical Specialists' curriculum was updated in 2002, and now also requires an understanding of the issues related to the clinical presentation, early recognition, epidemiology, management and control of infections which could potentially be deliberately released into a community for example, smallpox, anthrax, plague, botulism and tularaemia [9]. The need for similar training issues has been recognised by American researchers [12]. Although infectious disease clinicians will be involved, either directly or through consultation, in the management of any patient who has, or might have, an HID, neither model specifically mentions training in the management of HID, or training in preparedness for infectious disease emergencies. Relevant training for other health professionals (e.g. nurses, paramedical staff, infection control practitioners, clinic-managers) in Europe is, where it exists, even less standardised.

EUNID has therefore developed a core curriculum and an accompanying prototype training course that cover the theoretical and practical aspects of the management of patients with HID. Its objective was the creation of a common training framework in the EU in order to provide health professionals with the knowledge and skills needed to safely manage HID. EUNID defines an HID as an infectious disease that

- is transmissible from person to person;

- is life threatening;

- presents a serious hazard in the healthcare setting and the community;

- requires specific control measures.

The definition therefore includes SARS, viral haemorrhagic fevers (eg. Ebola, Lassa, Marburg and Crimean Congo haemorrhagic fevers), multi-drug and extensively-drug resistant tuberculosis (MDR- and XDR-TB) and smallpox. However, it excludes rabies and anthrax, which are lethal and require a specific public health response, but are not easily transmissible from person to person, and measles, which is easily transmissible but rarely lethal in developed countries [13]. This report describes the development and outlines the content of the curriculum and training course.

\section{Methods}

In April 2005, a questionnaire was sent to all EUNID partners about current training requirements in their country for healthcare professionals working in high-level isolation units and/or caring for patients with HID. The survey also sought the partners' views on whether formal, standardised training of such professionals in the management of HIDs was desirable, and asked them to list the key elements of an optimal training programme.
The EUNID coordination team then used the data obtained in the questionnaire to develop a draft core curriculum and an outline training course. The course was designed according to "outcomes-based education" principles; working "backwards" from the outcomes to be obtained by the trainees to the elements of the desired course (content, teaching and learning experiences, assessment, and evaluation), and recognising that trainees are more likely to retain information if they participate actively in the learning process, and if didactic teaching is backed up with practical, skillsbased, learning $[14,15,16]$.

\section{Results}

Representatives from five countries (Germany, Greece, Italy, Sweden and the United Kingdom) reported that some form of training in the management of HID was available in their country. They reported that this training was largely un-standardised, and mostly targeted to high-level isolation unit personnel, as were arrangements for regular updating of knowledge and skills.

Responders identified a need for training in the following key areas:

- disease-specific knowledge, including epidemiology and public health response;

- infection control including the correct use of personal protective equipment (PPE); decontamination, and the safe management of clinical waste;

- providing healthcare in the setting of a high-level isolation unit;

- the use of specialised medical devices and equipment (e.g. patient isolators; respirators) found in this setting.

Responders also suggested as additional training needs:

- bio-security, including safe transport of specimens and safe patient transfer;

- crisis management:

- regular exercises for patient care teams.

All EUNID partners who contributed to the development of the core curriculum and course outline highlighted the importance of practical skills-and-drills based training.

The curriculum therefore has two components: theoretical knowledge (Table 1) and practical skills (Table 2), each of which relate to the areas identified by consensus between EUNID partners as key to the management of HID. The course is designed to be taught over a minimum of three days in the setting of a healthcare facility with an attached high-level isolation unit. It consists of two integrated modules, matching the two components described in the curriculum. Module 1 "knowledge" provides the knowledge and evidence base for Module 2 "practical skills", which offers practical, skills-based training. A detailed course schedule, with outline content and timings is available on the EUNID website, where comments and input can also be given (http://www.eunid.com/index.asp) $[17,18]$. 
T A B L L 1

Proposed EUNID core curriculum for management of highly infectious diseases (HID): theoretical knowledge

\begin{tabular}{|c|c|}
\hline \multicolumn{2}{|l|}{ MODULE 1: KNOWLEDGE } \\
\hline Topic & The specialist should be able to describe/explain \\
\hline $\begin{array}{l}\text { Disease-specific } \\
\text { knowledge }\end{array}$ & $\begin{array}{l}\text { - Disease epidemiology and its public health impact } \\
\text { - Mode of transmission } \\
\text { - Clinical presentation, including early recognition, } \\
\text { differential diagnosis, investigation, and management } \\
\text { options } \\
\text { - Appropriate infection control measures } \\
\text { - Pre-and post-exposure preventive measures } \\
\text { - Appropriate management of hospital and family contact } \\
\text { - Appropriate management of an occupational exposure } \\
\text { - Sources of advanced technical advice including relevant } \\
\text { national and international guidelines }\end{array}$ \\
\hline $\begin{array}{l}\text { Public health and } \\
\text { HIDs }\end{array}$ & $\begin{array}{l}\text { - The principles of the public health response to HID } \\
\text { - Systems for notifying/reporting HID in their own and other } \\
\text { countries } \\
\text { - Epidemiologic characteristics that may distinguish a naturally } \\
\text { occurring outbreak from a deliberate release event } \\
\text { - How and when to involve public health authorities in } \\
\text { management of HID } \\
\text { - The concept of syndromic surveillance } \\
\text { - Public health responses to the deliberate release of biological } \\
\text { agents }\end{array}$ \\
\hline $\begin{array}{l}\text { Hospital infection } \\
\text { control }\end{array}$ & $\begin{array}{l}\text { - The different types of infection control precautions } \\
\text { (standard, contact, respiratory/droplet, airborne infection } \\
\text { isolation) and criteria for their use } \\
\text { - Country-specific HLIU isolation techniques and the } \\
\text { advantages and disadvantages of each } \\
\text { - Disease-specific high-risk procedures (e.g. aerosol- } \\
\text { generating procedures in SARS) and techniques for risk } \\
\text { reduction } \\
\text { - Sources of advanced technical advice including relevant } \\
\text { national and international guidelines }\end{array}$ \\
\hline $\begin{array}{l}\text { Personal protective } \\
\text { equipment (PPE) }\end{array}$ & $\begin{array}{l}\text { - The different types of respiratory and other PPE available } \\
\text { for use by healthcare workers, including specialised } \\
\text { respiratory protection, and the principles underlying the } \\
\text { selection of appropriate PPE } \\
\text { - Sources of advanced technical advice including relevant } \\
\text { national and international guidelines }\end{array}$ \\
\hline $\begin{array}{l}\text { Disinfection, } \\
\text { decontamination } \\
\text { and waste } \\
\text { management }\end{array}$ & $\begin{array}{l}\text { - Categories of disinfectant and their use in } \\
\text { management of HID } \\
\text { - Safe and appropriate decontamination of patients } \\
\text { and equipment } \\
\text { - Waste management issues, including resources for } \\
\text { assistance } \\
\text { - Sources of advanced technical advice including } \\
\text { relevant national and international guidelines }\end{array}$ \\
\hline Biosafety issues & $\begin{array}{l}\text { - Principles of biohazard groupings and risk } \\
\text { assessment } \\
\text { - Safe transportation of biohazard samples within } \\
\text { and between healthcare facilities in accordance with } \\
\text { current UNECE guidelines, including different types of } \\
\text { triple container } \\
\text { - Safe patient transfer within and between healthcare } \\
\text { facilities } \\
\text { - The procedures for handling a body post mortem } \\
\text { - Sources of advanced technical advice including } \\
\text { relevant national and international guidelines }\end{array}$ \\
\hline $\begin{array}{l}\text { High level isolation } \\
\text { units (HLIU) }\end{array}$ & $\begin{array}{l}\text { - The design and construction characteristics of a HLIU, } \\
\text { including air changes, pressure gradient and air filtering } \\
\text { - The different modalities of HLIU in the EU } \\
\text { - The differences between an isolation room and HLIU } \\
\text { - Criteria for advising patient admission to a HLIU } \\
\text { - Sources of advanced technical advice including relevant } \\
\text { national and international guidelines on unit design, } \\
\text { construction and maintenance }\end{array}$ \\
\hline
\end{tabular}

TA B L E 2

Proposed EUNID core curriculum for management of highly infectious diseases (HID): practical skills

\begin{tabular}{|c|c|}
\hline \multicolumn{2}{|c|}{ MODULE 2: PRACTICAL SKILLS } \\
\hline Topic & The specialist should be able to \\
\hline $\begin{array}{l}\text { Use of } \\
\text { respiratory } \\
\text { protection }\end{array}$ & $\begin{array}{l}\text { - Distinguish types of respiratory protection against infectious } \\
\text { agents available for health care workers (HCW) } \\
\text { - Demonstrate the correct selection, use, and safe } \\
\text { decontamination/disposal of each type } \\
\text { - Conduct a fit test and a fit check } \\
\text { - Detect problems with the use of each type of mask or respirator } \\
\text { - Show a fellow HCW how to use the mask or respirator }\end{array}$ \\
\hline $\begin{array}{l}\text { Infection } \\
\text { control } \\
\text { and use of } \\
\text { personal } \\
\text { protective } \\
\text { equipment PPE }\end{array}$ & $\begin{array}{l}\text { - Demonstrate the correct procedures for hand washing and use of } \\
\text { alcohol gels for hand cleaning } \\
\text { - Demonstrate the correct use and disposal of needles and sharp } \\
\text { instruments } \\
\text { - Demonstrate the correct use of aseptic technique } \\
\text { - Demonstrate the correct selection, use, and safe disposal of PPE } \\
\text { appropriate to the risk } \\
\text { - Detect and respond appropriately to problems with the use of an } \\
\text { article of PPE } \\
\text { - Recognise when PPE is being used inappropriately } \\
\text { - Assist/correct a fellow HCW with the proper process of donning/ } \\
\text { removing PPE }\end{array}$ \\
\hline $\begin{array}{l}\text { High level } \\
\text { isolation unit } \\
\text { (HLIU) }\end{array}$ & $\begin{array}{l}\text { - Conduct basic airflow/pressure checks } \\
\text { - Check a planned preventive maintenance schedule and its } \\
\text { results, and discuss these with the facility engineer } \\
\text { - Have participated in patient admission drills/exercises }\end{array}$ \\
\hline Team working & $\begin{array}{l}\text { - Demonstrate experience of the team work and coordination } \\
\text { needed to deal with a HID patient } \\
\text { - Respond appropriately to an occupational exposure incident (e.g. } \\
\text { blood splash, glove tear) } \\
\text { - Have participated in patient admission drills/exercises }\end{array}$ \\
\hline $\begin{array}{c}\text { Country - } \\
\text { specific skills }\end{array}$ & $\begin{array}{l}\text { - Safely use the country-specific HLIU equipment relevant to their } \\
\text { home country } \\
\text { - Demonstrate an awareness of country-specific HLIU equipment } \\
\text { used elsewhere, including its limitations and necessary infection } \\
\text { control precautions }\end{array}$ \\
\hline
\end{tabular}

The aim of the "knowledge" module is to introduce the trainees to the clinical aspects of HID and their impact on public health, and to the principles of infection control, including selection and use of personal protective equipment, disinfection and waste management, through didactic teaching and class-based discussion. The module consists of a series of 12 lectures, which require a minimum total teaching time of 10 hours. The learning objectives for each lecture or subgroup of lectures match those outlined in Table 1.

The "practical skills" module requires a minimum of eight hours training time. It consists of three skill stations that cover the use of respiratory equipment, PPE, and country-specific medical equipment, e.g. patient isolator. A lecture is incorporated into an on-site tour of a functioning high-level isolation unit and during four clinical scenario exercises the trainees work in small groups to manage a patient. The skill stations are modelled on those offered in internationally recognised resuscitation courses (e.g. ACLS(, ATLS( )), where, with the assistance of an experienced trainer, trainees practise a particular skill in groups of four to five people. The clinical scenario exercises are intended to give trainees the opportunity to work together as an interdisciplinary team, to experience working in the setting of a high-level isolation unit, and to use the knowledge and practice the skills they learned during the course.

Learning material (course manual, selected texts, e-learning activities) should be made available to trainees at least six weeks before the course, to encourage their active participation and 
ensure that everyone has the opportunity to start the course with the same level of basic knowledge. Trainees are expected to have reviewed all course materials before attending the course.

EUNID partners agreed that the course should be accompanied by an assessment of the performance of trainees and trainers, and an assessment of the training material [19]. The evaluation of trainees should have three elements: a pre-course test, an in-course assessment of performance in skill stations and clinical scenarios, and a post-course test. The pre- and post-course tests would both consist of multiple choice questions, either web- or hardcopybased, drawn from a pool of questions developed by experts in the management of HID or infectious disease emergencies and piloted to ensure consistency and suitability. The pre-course test should be provided to trainees at the same time as the course material, and completed as part of the pre-course preparation. Trainees should be given their test score by the course organiser at registration, and have an opportunity to discuss issues about which they were uncertain with a trainer. Trainees would take the post-course test on the final day of the course, and the results of the post-course test, coupled with performance at the clinical scenario stations, would form the basis of the final trainee assessment.

Trainees should be given the opportunity to evaluate the training material, the course, the facility, the lectures and the skill stations/ clinical scenarios. The training faculty should collectively review these evaluations, which should be used to refine the course content and retained for use in benchmarking future courses.

\section{Discussion}

The events of 2001 in the US (e.g. the World Trade Center attack and the deliberate release of anthrax spores) forced a reassessment of global health security, revealing gaps in clinical, laboratory and public health capacity to respond effectively to infectious disease emergencies, including those that involve highly infectious diseases.

Multiple studies support the intuitive association between higher provider practice and better clinical outcomes ("practice makes perfect") $[20,21]$, but few clinicians or public health practitioners working in the EU have first hand experience of highly infectious diseases gained from direct involvement in case management. In the 2002-2003 SARS epidemic, only seven of the current 27 EU member states reported probable cases of SARS: seven in France; nine in Germany; four in Italy; five in Sweden; four in the United Kingdom; one in Ireland; and one in Spain $[22,23,24]$. Most clinicians now in practice have never seen a case of smallpox. Haemorrhagic fever virus infections are imported to Europe sufficiently often to require preparedness, and but not frequently enough to generate widespread clinical expertise or confidence in their management $[25,26,27]$.

Given this situation, there is a need for continued education and training of the healthcare professionals likely to be involved in diagnosis, management and response to infectious disease emergencies involving HID. Most preparedness and response plans recognise this, and considerable resources have been invested in developing national guidelines, fact sheets, incident response check lists, teaching slide sets, decision-based algorithms for diagnosis, and clinical management pathways for highly infectious diseases.
However, public health preparedness for many nations cannot be achieved by national initiatives alone, but requires a cohesive international programme that includes collaborative training. EPIET aims to improve the response capacity of public health professionals in Europe and neighbouring countries and now also covers bioterrorism and rapid assessment of emergencies [28]. However, there is no equivalent common framework for training in the clinical setting in Europe, where the ways in which highly infectious diseases are managed vary considerably between and within countries.

The core curriculum and accompanying course outlined here are intended to help standardise and augment current training on the management of HID in Europe, and to complement, rather than duplicate, work undertaken by the European Centre for Disease Prevention and Control (ECDC), and to interface with other training programmes in public health and field epidemiology (EPIET, Training Programme in Epidemiology and Public Health Interventions Network - TEPHINET, http://www.tephinet.org). The described training tools have the advantage of being shaped through consensus by clinicians with a broad range of expertise in infectious disease and public health who have experience in identifying and meeting training needs within their own institutions, which include high security isolation units. The curriculum has been designed in a way that, if desired, it could, be integrated into existing training curricula for infectious disease medicine, other medical specialties, or other disciplines. The course is targeted primarily at infectious disease clinicians and other hospital-based healthcare professionals (including hospital infection control practitioners, intensive care personnel, emergency medicine practitioners, nurseconsultants, clinic-managers/administrators), who would be most likely be directly involved in the multidisciplinary management of an infected patient. It also puts a strong emphasis on the public health response to infectious disease emergencies, and could be used to cross-train public health practitioners, and others (e.g. paramedics, laboratory workers, health emergency planning advisors) who might be involved in major infectious disease incident management.

The course as described is intended to be taught over three days on site in a healthcare facility with an attached high level isolation unit, so that trainees can gain exposure to the specialised equipment and techniques used in such units. We believe that a three-day course would, given time and cost constraints, be more accessible to trainees than a longer one, but we recognise that the course is very tightly scheduled. We are convinced that the schedule is feasible provided that trainees undertake the pre-course preparation as intended, and the course itself is well organised.

The development of the curriculum and course in the future will improve the sharing of experience between healthcare professionals from different countries, and the experience of participation in a common European training course, based on a common core curriculum, will facilitate communication and collaboration during a real international public health emergency. We hope that trainees who have completed the course will be able to contribute to health protection in Europe, and to the broader European response to infectious disease emergencies. EUNID intends to apply for European continuing medical education (CME) accreditation for the course from the European Board for Accreditation in Infectious Diseases (EBAID) and will also seek the opinion of the European Union of Medical Specialists Section of Infectious Diseases on the curriculum and course content [29]. 
* Further members of European Network for Infectious Diseases: Renaat Peleman, Belgium; Ida Gjorup, Denmark; Kuulo Kutsar, Estonia; Christian Perronne, France; Helena Maltezou, Greece; Gerard Shehaan, Ireland; Robert Hemmer, Luxembourg; Andy I. M. Hoepelman, The Netherlands; Kamal Mansinho, Portugal; Antoni Trilla, Spain, Magda Campins Marti, Spain; Boo Jarhall, Sweden. This work was partly supported by the EC grant EUNID (2003207), and by the Ministero della Salute, Italia - Ricerca Corrente, Istituti di Ricovero e Cura a Carattere Scientifico.

\section{References}

1. Jernigan JA, Stephens DS, Ashford DA, et al. Bioterrorism-related inhalational anthrax: the first 10 cases reported in the United States. Emerg Infect Dis 2001; 7:933-944.

2. Hughes JM, Gerberding JL. Anthrax bioterrorism: lessons learned and future directions. Emerg Inf Dis 2002; 8:1013-1014.

3. National Advisory Committee on SARS and Public Health. 2003. Learning from SARS: renewal of public health in Canada. Health Canada. Ottawa, Canada, 2003.

4. World Health Organization. Summary of probable SARS cases with onset of illness from 1 November 2002 to 31 July 2003. Based on data as of 31 December 2003. Available from: http://www.who.int/csr/sars/country/table2004_04_21/en/index.html (accessed 22 May 2006).

5. Crowcroft N, Morgan D, Brown D,. Viral haemorrhagic fevers in Europe - Effective control requires a co-ordinated response. Euro Surveill 2002;7(3):31-32. Available from: http://www.eurosurveillance.org/em/v07n03/0703-221.asp

6. Programme of cooperation on preparedness and response to biological and chemical agent attacks, [Health Security], 17/12/2001. Available from: http://www.europa. eu.int/comm/health/ph_threats/Bioterrorisme/bioterrorism01_en.pdf

7. McKendrick MW. The European Union Medical Specialties core training curriculum in infectious diseases: overview of national systems and distribution of specialists. Clin Microbiol Infect 2005; 11(Suppl 1):28-32.

8. Cooke FJ, Choubina P, Holmes AH. Postgraduate training in infectious diseases: investigating the current status in the international community. Lancet Infect Dis 2005; 5:440-49.

9. European Union of Medical Specialties. UEMS training curriculum in infectious diseases. Available from: http://www.escmid.org/Files/UEMS\%20Training\%20Curriculum\%20ID. pdf

10. Norrby SR, Carbon C. Report of working group 3: specialist training and continuing medical education/professional development in the infection disciplines. Clin Microbiol Infect 2005;11 (Suppl 1):46-9.

11. Joiner KA, Powderly WG, Blaser MJ et al. Fellowship in Infectious Diseases: A report from the regional and National Meetings of Infectious Diseases Division Chiefs and Program Directors. Clin Infect Dis 1998; 26:1060-5.

12. Noah DL, Sobel AL, Ostroff SM, Kildew JA. Biological warfare training. Infectious disease outbreak differentiation criteria. Ann N Y Acad Sci 1999; 894:37-43.

13. EUNID. Report of the first annual meeting, May 27-28, Rome, 2005. Available from: http://www.eunid.com/privato/upload_folder/Final\%20EUNID2005\%20meeting\%2
Oreport.pdf

14. Prideaux D. ABC of learning and teaching in medicine. Curriculum design. BMJ 2003; 326: 268-270.

15. Kaufman DM. Applying educational theory in practice. BMJ 2003; 326:213-216.

16. Abrahamson SD, Canzian S, Brunet F. Using simulation for training and to change protocol during the outbreak of severe acute respiratory syndrome. Crit Care 2006 Feb;10(1):R3

17. EUNID. Report of the second annual meeting, April 7-8, London, 2006. Available from: http://www.eunid.com/privato/upload_folder/EUNID\%20meeting\%20repor t\%20-\%20London\%202006.pdf

18. EUNID. Suggested prototype EUNID course schedule for the management of patients with highly infectious diseases. Available from: http://www.eunid. com/privato/partners/doc_partners.asp

19. EUNID. Course for the management of patients with highly infectious diseases: content of knowledge and skills modules. Available from: http://www.eunid. com/privato/partners/doc_partners.asp

20. Morrison J. ABC of learning and teaching in medicine. Evaluation. BMJ 2003 326:385-387.

21. Halm EA, Lee C, Chassin MR. Is volume related to outcome in healthcare? A systematic review and methodologic critique of the literature. Ann Intern Med. 2002; 137:511-520.

22. Liu JH, Zingmond DS, McGory ML, Soo Hoo NF, Ettner SL, Brook RH, Ko CY. Disparities in the utilization of high-volume hospitals for complex surgery. JAMA. 2006; 296(16): 1973-80.

23. D. Radun 1 , M. Niedrig 2, A. Ammon et al SARS: Retrospective cohort study among German guests of the Hotel 'M', Hong Kong. Euro Surveill 2003;8(12): 228-230. Available from: http://www.eurosurveillance.org/em/v08n12/0812-222. asp

24. B Issartel, 0 Lesens, C Chidiac, et al. Suspected SARS patients hospitalised in French isolation units during the early SARS epidemic: The French experience. Euro Surveill 2005;10(3):9-43. Available from: http://www.eurosurveillance. org/em/v10n03/1003-222.asp

25. Donoso Mantke O, Schmitz H, Zeller H, Heyman P, Papa A, Niedrig M. Quality assurance for the diagnostics of viral diseases to enhance the emergency preparedness in Europe. Euro Surveill 2005;10(6):102-6. Available from: http:/l www.eurosurveillance.org/em/v10n06/1006-221.asp

26. Promed-mail. Lassa fever - Europe ex Sierra Leone (02). Archive number 20060724.2045. Available from: http://www.promedmail.org/pls/promed/ f?p=2400:1001:::N0::F2400_P1001_BACK_PAGE,F2400_P1001_PUB_MAIL ID:1000\%2C33712

27. Macher AM, Wolfe MS. Historical Lassa fever reports and 30-year clinical update. Emerg Inf Dis 2006; 12(5):835-7

28. Coignard B. Bioterrorism preparedness and response in European public health institutes. Euro Surveill 2001; 5:159-165. Available from: http://www. eurosurveillance.org/em/v06n11/0611-222.asp

29. ESCMID (European Society for Clinical Microbiology and Infectious Disease) Accreditation of CME in Clinical Microbiology or Infectious Diseases: http:// www.escmid.org/sites/index_f.aspx?par=2.6

Citation style for this article: Baka A, Fusco F, Puro V, Vetter N, Skinhoj P, Ott K, and al. A curriculum for training healthcare workers in the management of highly infectious diseases. Euro Surveill 2007;12(6)[Epub ahead of print]. Available online: http://www.eurosurveillance.org/em/v12n06/1206-223.asp 